GOMES, JFB; GOMES, RSB; SOUZA, AO. 2019. The multifunctionality of urban horticulture and its integration with the city ecosystem: a brief review of concepts and the case of São Luís. Horticultura Brasileira 37: 252-259. DOI - http://dx.doi.org/10.1590/S0102-053620190301

\title{
The multifunctionality of urban horticulture and its integration with the city ecosystem: a brief review of concepts and the case of São Luís
}

\author{
João Flávio B Gomes ${ }^{1} \mathbb{D}$; Renata SB Gomes ${ }^{1} \mathbb{D}$; Alex O Souza ${ }^{2} \mathbb{D}$ \\ ${ }^{1}$ Embrapa Cocais, São Luís-MA, Brasil; joaoflavio.gomes@embrapa.br; renata.bomfim@embrapa.br; ${ }^{2}$ Universidade Estadual do Maranhão \\ (UEMA), Departamento de Arquitetura e Urbanismo, São Luís-MA, Brasil; oliveira.alex@live.com
}

\begin{abstract}
Urban agriculture is currently carried out all over the world. The activity is characterized by its multifunctionality, contributing to food security, preservation of biodiversity, better use of urban spaces, and proper management of soil and water, in addition to contributing to increasing income and improving the quality of life of farmers who live in the cities. In the 1980s and 1990s, urban agriculture gained momentum on the international scene and, from 2005, in Brazil. Some successful experiences in the world (Detroit, Havana, and St. Petersburg) and in Brazil (Teresina, Sao Paulo, and Belo Horizonte) are briefly reported here. Then, we describe in more detail the case of the city of São Luís. The municipality is situated on an island and its rural spaces have characteristics of peri-urban areas. Agricultural production has low expression in municipal GDP (Gross Development Product). The main products are papaya, cassava, beans, bananas, coconut, and passion fruit and, among the vegetables, roselle, chives, coriander, and West Indian gherkin, traditional regional species of Maranhão cuisine. The activity has two primary groups of actors: producers and intermediaries, with 83 and $41 \%$ of them, respectively, living in rural areas. Almost all producers $(92 \%)$ use their area, $79 \%$ use some sustainable fertilization practice, and $69 \%$ do not use pesticides. Production areas are small and producers need technical assistance. Transport and poor road conditions are the main challenges to bring products to the markets. The reality that came out from our study indicates the lack of public support to urban farmers in São Luís. On the contrary, successful experiences of urban agriculture have in common the convergence of public policies of urban planning, agriculture and supply, education, and health. Urban agriculture is dynamic and must be integrated into the urban ecosystem to make it possible to unveiling new perspectives on the countryside-city relationship.
\end{abstract}

Keywords: Urban- and peri-urban agriculture, public policies, production chains, socioeconomic analysis, diagnosis, scenarios.

\section{RESUMO}

A multifuncionalidade da horticultura urbana e sua integração ao ecossistema das cidades: uma breve revisão de conceitos e o caso da cidade de São Luís

A agricultura urbana está presente hoje em todo o mundo. A atividade caracteriza-se por sua multifuncionalidade, contribuindo para a segurança alimentar, preservação da biodiversidade, melhor aproveitamento dos espaços urbanos e manejo adequado de solo e água, além de colaborar para o incremento da renda e melhoria da qualidade de vida dos agricultores que vivem nas cidades.Nos anos 80 e 90 a agricultura urbana ganhou momento no cenário internacional e, a partir de 2005, no Brasil. Algumas experiências exitosas no mundo (Detroit, Havana e São Petersburgo) e no Brasil (Teresina, São Paulo e Belo Horizonte) são brevemente relatadas antes de nos determos no caso da cidade de São Luís. O município é situado em uma ilha e seus espaços rurais têm características de áreas periurbanas. A produção agrícola possui baixa expressividade no PIB municipal. Os principais produtos são mamão, mandioca, feijão, banana, coco e maracujá e, entre as hortaliças, vinagreira, cheiro-verde e maxixe, espécies regionais tradicionais da culinária maranhense. A atividade possui dois grupos básicos de atores: produtores e atravessadores, sendo que 83 e $41 \%$ deles, respectivamente, vivem na zona rural. Quase todos os produtores (92\%) cultivam em área própria, $79 \%$ utilizam alguma prática sustentável de adubação e $69 \%$ não usam agrotóxicos. As áreas de produção são pequenas e os produtores carecem de assistência técnica. Transporte e má condição das estradas são os principais desafios para levar os produtos para as feiras. A realidade apreendida indica, de forma geral, falta de apoio público aos agricultores urbanos em São Luís. Ao contrário, experiências exitosas de agricultura urbana têm em comum a convergência de políticas públicas de planejamento urbano, agricultura e abastecimento, educação e saúde. A agricultura urbana é dinâmica e deve estar integrada ao ecossistema urbano, de forma a tornar possível lançar novos olhares sobre a relação campo-cidade.

Palavras-chave: Agricultura urbana e periurbana, políticas públicas, cadeias de produção, análise socioeconômica, diagnóstico, cenários.

Received on June 28, 2019; accepted on October 24, 2019 
$T^{1}$ he urban population is likely to reach six billion people by 2050 or $66.7 \%$ of the world's total population, compared to $53.6 \%$ in 2014 (United Nations, 2015). The report The State of Food Insecurity in the World 2015 shows that food insecurity threatens 795 million people worldwide (FAO, 2015). Such scenario presents two significant challenges: how and where to produce more food and how to ensure food security and conservation of natural resources simultaneously. The use of intra- and peri-urban areas for agriculture, known as urban agriculture, is one of the alternatives in many countries. According to the United Nations Food and Agriculture Organization (FAO, 2015), urban agriculture is already practiced by 800 million people worldwide.

Urban agriculture is currently a universal practice (Boukharaeva et al., 2007) and became an alternative to respond to the challenges posed by the increasing urbanization. Urban agriculture plays a vital role in supplying food systems in cities, in close connection to food security, biodiversity preservation, better use of urban spaces, and proper soil and water management (Mougeot, 2000, apud Machado \& Machado, 2002). Besides, urban agriculture contributes to increase incomes and improve the quality of life of the farmers who, for one reason or another, migrated to the city.

There are successful experiences in various developed and developing countries of integrating urban agriculture into the urban ecosystem through city planning and management, resulting in mutual benefits for both the cities and the citizens. Leading experts in urban agriculture emphasize its multifunctionality and its ability to provide quality food for the population, preserving natural resources, increasing the incomes of the most vulnerable groups, and integrating both intraand peri-urban areas into the urban ecosystem (Mougeot, 2000a;Smit et al., 2001; Machado \& Machado, 2002).

Knowing and understanding the dynamics of urban agriculture within the urban ecosystem has been the object of several research areas. Urban planners, geographers, agronomists, sociologists, economists, in governmental and non-governmental organizations, are studying and seeking ways to make the multifunctionality of urban agriculture and its economic, social and environmental advantages increasingly more valuable to the cities and their population.

Urban- and peri-urban agriculture and the city: far beyond concepts

Cities and agricultural practices have been intrinsically connected from the beginning of the first urban centers, still in the Neolithic period $(3,500$ 3,000 BC). Agriculture was the main activity of those human nuclei up to their development into cities, where those not involved with agriculture, carried out other activities, such as building houses, places of worship and fences, or were involved in several other services. Producers had the duty of feeding the others with the surplus of their harvests (Benevolo, 2011). Therefore, since the Neolithic agricultural revolution, when men went from being a predator-gatherer to a domesticator-farmer (Mazoyer \& Roudart, 2010), agriculture was already an urban activity. Nevertheless, the term "urban agriculture" or "intra- and peri-urban agriculture" was coined only recently and came to the spot just a few decades ago (Mougeot, 2000b). The United Nations Program for Human Settlements (Unhabitat) brought the terminology to the international scene in the early 1980 s by starting the discussions on a new way of thinking the cities (Gomes, 2016).

The researcher Jac Smit, considered the "father of urban agriculture," is the leading author of the book Urban Agriculture: food, jobs and sustainable cities, launched at the Urban World Forum, in Istanbul, in 1996, by the United Nations Development Program (UNDP). The book is a reference to the academia and organizations that study and work with urban agriculture and is the first work published on the theme with scientific rigor. It is based on studies carried out from visits made to twenty countries between 1992 and 1994, as well as incursions to another ten countries after that date. In 2001, the author, along with the researchers Annu Ratta and Joe Nasr, released an updated revision of the first book, updating the development of discussions regarding urban agriculture. These authors propose a fundamental concept of urban agriculture, recognizing the agricultural practices observed in their research as existing in the city or metropolis in intra- or peri-urban areas, depending on the size of the city. Urban agriculture production chains were already structured in the countries visited, once the reported experiences show urban agriculture as an industry that produces, processes, commercializes, and distributes food to the urban population (Smit et al., 1996).

In the 2000s, Luc Mougeot published the report Urban Agriculture: definition, presence, potentials and risks, and policy challenges, a component of the Cities Feeding People series, funded by the International Development Research Center (IDRC) (Mougeot, 2000a). In the paper, Mougeot (2000a) stresses that the emergence of the term urban agriculture in the media and of urban agriculture experiences around the world increased the responsibility of researchers in seeking a conceptual consensus, mainly to avoid the misuse of the terminology and to make it perfectly understandable and transformative. For the author, "[...] the concept must be sufficiently clear to allow users to easily realize its potential for complementarity and synergy with other correlated concepts." Thus, Mougeot (2000a) suggested that the momentum went much beyond being acquainted with urban agriculture, but, actually, it was a matter of understanding how urban agriculture relates to other concepts, especially to the urban ecosystem. Mougeot (2000a) suggested some parameters to characterize urban agriculture and therefore to distinguish it from rural agriculture: the types of economic activity, the intra- or periurban location, the singularity of the areas where it is practiced, its scale and production system, and product categories, subcategories (food and non-food) and destination. Mougeot's studies (2000a) contributed significantly to the discussion and to fostering urban agriculture globally. 
The multifunctionality of urban horticulture and the sustainability

There is an urban agriculture characteristic that authors do not dispute: its multifunctionality. The benefits of urban agriculture for individuals, families, and the community are countless, notably food security, health improvement, income increase, and conservation of natural resources.

Urban agriculture and its multifunctionality were officially recognized in 1999 during the $15^{\text {th }}$ session of the Agriculture Committee (COAG), held in Rome. COAG pointed out urban agriculture's potential to address severe urban issues, including reducing food insecurity and building cities that are more resilient during crises (Arruda, 2011). Following the $15^{\text {th }} \mathrm{COAG}$ session, the World Food Summit, in 2002, and the UN High-Level Task Force on the Global Food Crisis, in 2008, recognized urban and peri-urban agriculture as viable and essential alternatives to produce food (Arruda, 2011).

In Brazil, the discussion on urban agriculture landed in connection to the food and nutrition security agenda. Agricultura Familiar e Agroecologia (AS-PTA) (Family Agriculture and Agroecology) produced a consistent report to support discussions around a National Urban Agriculture Policy (Assessoria e Serviços a Projetos em Agricultura Alternativa, 2015). In Brazil, concepts and characteristics of urban agriculture converged from the Fome Zero Program (Zero Hunger) and the inclusion of community gardens and were fully integrated into the context of food and nutrition security (Assessoria e Serviços a Projetos em Agricultura Alternativa, 2015). During the $2^{\text {nd }}$ and $3^{\text {rd }}$ National Food and Nutrition Security Conferences (CNSAN), held between 2004 and 2007 (Assessoria e Serviços a Projetos em Agricultura Alternativa, 2015), urban agriculture emerged as a priority means to supply food to the cities. A more specific and in-depth discussion on urban agriculture was, then, emerging.

In 2007, the national survey Panorama da Agricultura Urbana e Periurbana no Brasil e Diretrizes Politicas para sua Promoção: identificação e caracterização de iniciativas de AUP em regiões metropolitanas brasileiras (Picture of Urban and Peri-urban Agriculture in Brazil and Policy Guidelines for its Promotion: identification and characterization of urban agriculture initiatives in Brazilian metropolitan regions) was carried out (Santandreu \& Lovo, 2007). This work, a milestone in Brazil, resulted from a very consistent effort to diagnose urban agriculture in the country. The survey gathered the joint support of the federal government, social organizations and movements, and universities. Santandreu \& Lovo (2007) state that urban and peri-urban agriculture is a multidimensional concept, as it encompasses production, agro-extractivism and gathering, transformation and marketing, which can be practiced in intra- and periurban spaces, being linked to the city or metropolitan dynamics.

In 2009, the federal government, this turn through the Ministério de Desenvolvimento Social e Combate a Fome (MDS) (Ministry of Social Development and Hunger Alleviation), launched the project Support Center for Urban and Peri-urban Agriculture (CAAUP). CAAUP became part of the National Plan for Food and Nutrition Security (PLANSAN) already in the following year, during the $4^{\text {th }}$ CNSAN. The PLANSAN anticipated actions for the period 2012-2015, with the priority goal of implementing the National Urban Agriculture Policy, under MDS responsibility (Assessoria e Serviços a Projetos em Agricultura Alternativa, 2015). No other noteworthy meeting or breakthrough happened since then.

Successful urban horticulture experiences in Brazil and abroad

We will present three experiences abroad (Havana, St. Petersburg, and Detroit) and three experiences in Brazil (Teresina, Sao Paulo, and Belo Horizonte) among the many successful urban agriculture experiences around the world.

Community gardens are examples of agriculture that take place in urban space. In Cuba, public policies foster agricultural activities within the cities, such as intensive vegetable gardens, company and factory gardens, and suburban farms, among others (Companioni et al., 1997, apud Bourque \& Cañizares, 2000). In Havana, urban agriculture has strong governmental support, and urban production is quite representative to the Cuban economy. The severe financial crisis that struck the country in the early 1990 s left Cubans unable to bring products from the countryside to the cities due to fuel shortages. Hence, the population began to use the empty spaces in the cities as cropping areas: "[...] many of the first vegetable gardens were sown in adjacent plots, patios and terraces, by families who sought to feed themselves once they realized that market shelves became increasingly empty" (Bourque \& Cañizares, 2000).

In St. Petersburg, urban agriculture is widely practiced, especially by citizens between 35-45 years. Russians use rudimentary and organic practices and their main production goals are self-consumption and supplementing incomes, as the population spends around $60 \%$ of the budget buying products in markets (Moldakov, 2000). Community gardens are relevant in the urban landscape and are taken into consideration in St. Petersburg's urban planning and management (Moldakov, 2000). Russian legislation encourages and supports the development of urban agriculture in intra- and peri-urban spaces. A clause compels the country to support gardeners' associations by building urban structures to favor the production, distribution, and commercialization of urban agricultural products (Moldakov, 2000).

Urban agriculture is present in developed countries as well, from a historical perspective. Detroit, USA, used the experience of European cities to install community gardens. Vegetable gardens became a viable alternative to reduce the negative social and economic impacts of the financial crisis of the $90 \mathrm{~s}$, back in the nineteenth century, reducing unemployment, improving the nutritional standard of the population and generating income in a city devastated by the economic crisis (Branco \& Hanson, 2011, apud Castelo Branco \& Alcântara, 2012). 
Branco \& Hanson (2011, apud Castelo Branco \& Alcântara, 2012) surveyed the situation of community gardens in 22 US states and noted that the initiatives were born from individuals or groups of individuals aiming to produce their own food, organize cooperation networks with the aid of some institution or help the poor and the population with restricted access to food in the city. The dynamics consisted of social organization around an unoccupied space previously negotiated with the owner to install a vegetable garden.

The survey indicated that food security in the US was not a responsibility of the public sector in general and that actions on the issue were of private initiative (Branco \& Hanson, 2011, apud Castelo Branco \& Alcântara, 2012). In Brazil, it goes in the other way. Federal, state, and municipal governments assumed the responsibility for food security through the development and implementation of public policies. In the US, most community gardens are in urban areas, followed by suburban (or peri-urban) areas and, to a lesser extent, rural areas (Branco \& Hanson, 2011, apud Castelo Branco \& Alcântara, 2012). Gardens are relatively small, $70 \%$ of them with up to $2,000 \mathrm{~m}^{2}$. Organic farming is the predominant production system, which confirms the potential of urban agriculture for the conservation and preservation of natural resources within cities, once the avoidance of pesticides preserves soil and water from contamination, ultimately protecting public health.

Turning to Brazil, Itararé, a city in the neighborhood of Teresina, the largest city and capital of the state of Piauí, houses the most extensive community garden in an urban area in Latin America (Sinimbu, 2015). There are also successful initiatives in metropolitan regions, such as Belo Horizonte and São Paulo, and in countless other Brazilian cities (Portal da Agricultura Urbana e Periurbana, 2016), which developed actions and promoted the production, distribution, and commercialization of animal and vegetable products in urban spaces (Santandreu \& Lovo, 2007).

The city of Teresina occupies 1,809 $\mathrm{km}^{2}$, of which the capital (urban area) uses only $228.31 \mathrm{~km}^{2}$ or $12.6 \%$ of the total (Teresina, 2000). Aware of the large idle area, the Municipal Secretariat of Agriculture and Food Supply (SEMAB) implemented community gardens as its main action to face the challenges of reducing the volume of fruit and vegetable imports and supplying the city demands. Teresina used to import slightly more than $90 \%$ of its demands of vegetables and fruits from other regions, most from Serra do Ibiapaba, in the state of Ceará, but also from the states of São Paulo, Pernambuco, Bahia and Maranhão, which represented an important drain of financial resources to the state of Piauí (Teresina, 2000).The program also aimed at generating jobs, increasing incomes, and improving the food intake of the covered families(Teresina, 2000).

The city set community gardens in urban areas identified as large pockets of poverty, where beneficiary families came predominantly from rural areas, migrating mainly from the state of Piauí, but also Maranhão, Ceará, Pará, and Tocantins, and do not have work or employment, thus posing economic and social challenges (Teresina, 2000). Community gardens had co-management (community and city) and the use of unproductive areas as their basic premises. At the time of implementation, the program included 2,503 families, covered 116.6 hectares, and installed 38 gardens. The demand came primarily from the expansion zone of the urban perimeter, where low-income families concentrate. In Teresina's experience, the municipal public agency (SEMAB) acknowledged the multifunctionality of urban agriculture through participatory planning with the involved communities, favoring actions for income increase, food and nutritional security, and social use of unproductive land, promoting positive changes for both the communities and the city.

The Municipal Policy to Support Urban Agriculture (Municipal Law No. 10.255/2011) in Belo Horizonte, a 3-million people city (IBGE, 2011), has supported urban agricultural practices since 2011. After discussions about the revision of the city master plan in 2010 , Law No. 9,959/2010 was approved, updating the Urban Land Use and Occupation Law and including urban agriculture as an economic activity defined as a legal land use category in the city (Belo Horizonte, 2011).

São Paulo, a megalopolis with just over 11 million inhabitants (IBGE, 2011), bears numerous urban agriculture initiatives. Regarding public policies, the city created the Urban and Peri-urban Agriculture Program (PROAURP), through Law No. 13,727/04, regulated by Decree No. 51,810/10, and included urban and peri-urban agriculture in its strategic master plan (Section X, Chapter III). PROAURP contemplated several thematic axes of municipal management, namely the fostering of agriculture and technical assistance, strengthening of central and vicinal markets, local development, better integration of the links of the food supply system, practice of the city and property social functions, and environmental education (São Paulo, 2004). São Paulo experience is remarkable also for recognizing the fundamental role of various local actors, as well as their integration, for achieving the success: public and private schools, health units, rural and urban producers, local communities, non-governmental organizations, social welfare institutions, and several municipal departments are eligible to integrate the program (São Paulo, 2016).

Socio-spatial characterization of the urban horticulture in São Luís Island: a challenge for the city

São Luís Island (from $02^{\circ} 22$ '23" to $02^{\circ} 51^{\prime} 00^{\prime \prime} \mathrm{S}$; from $44^{\circ} 26^{\prime} 41^{\prime \prime}$ to $\left.43^{\circ} 59^{\prime} 41^{\prime \prime} \mathrm{W}\right)$ is located in the North of the state of Maranhão, in Northeast Brazil. The island is close to the coastal region, with the Atlantic Ocean to the North, San Jose Bay and the Mosquito Strait to the South, San Jose Bay again to the East, and San Marcos Bay to the West. The island is a regional segment of the Brazilian coast located in the geological-morphological feature of Golfão Maranhense and composes a large and complex estuarine system, where São Marcos and São José Bays stand out (IMESC, 2014). The population on the island is $1,309,330$ inhabitants and, the demographic density, 927.11 inhabitants per $\mathrm{km}^{2}$. São Luís is the state 
capital and the island main city. The remaining municipalities in the island are Paço do Lumiar, Raposa, and São José de Ribamar (Figure 1).

São Luís edaphoclimatic conditions are suitable for growing vegetables, fruits, and medicinal plants, among other crops. The several São Luís rural centers concentrate in the so-called rural area of the municipality, which, in fact, is not rural, but peri-urban. Therefore, the agriculture carried out in São Luís is actually in the domain of urban agriculture. Although numerous, the city agricultural production areas do not guarantee a safe margin for the municipal food supply. Data from the Maranhão Hortifrutigranjeiros Cooperative (Gomes, 2016) indicate that most of São Luís vegetable supply comes from other states, the production from Maranhão ranking $8^{\text {th }}$ only (Figure 2). The contribution of São Luís agricultural production to the municipal GDP is still minimal (IBGE, 2014). The main products are papaya, cassava, beans, bananas, coconut, and passion fruit. Production areas are rather small and demand efficient management techniques and technical assistance to increase street-market vendors the productivity.

Gomes (2016) interviewed 118 street-market vendors as part of a study carried out in São Luís and found out that $48(36 \%)$ were farmers selling their own products, while 70 (64\%) were intermediaries. The result highlighted the strong presence of the intermediary, revealing the complexity of the horticultural value chain in São Luís Island. Public policies related to urban planning should give intermediaries their real relevance as social actors, as

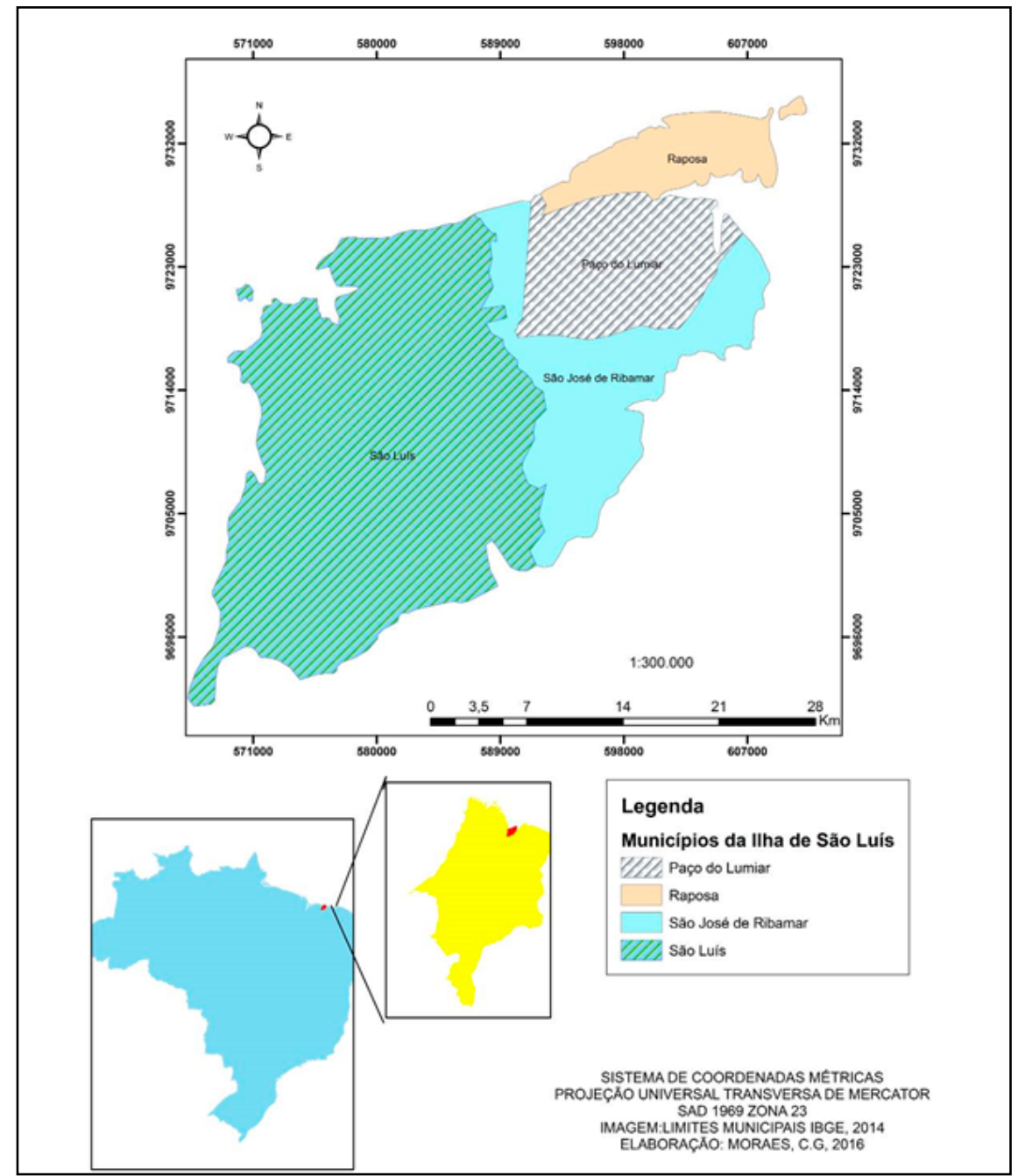

Figure 1. Municipalities and geographic allocation of São Luís Island, Maranhão State, Brasil (Source: Gomes, 2016). São Luís, Embrapa Cocais, 2016. well as foster actions to mitigate the impact of other factors that make the local agricultural production nearly unfeasible, such as high production costs, low qualification of producers, difficulties in supplying agricultural inputs and technological limitations.

Most producers and intermediaries live in rural areas. However, while $83 \%$ of farmers do reside in rural areas, less than half of the intermediaries (41\%) actually does, although the figure is still higher than the intermediaries who live in urban areas $(33 \%)$. Most producers and intermediaries sell in São Luís (77\% and $83 \%$, respectively), followed by Paço do Lumiar (21\% for producers and $3 \%$ for intermediaries), with $14 \%$ of intermediaries declining to answer. These figures indicate that the two municipalities, São Luís and Paço do Lumiar, should include producers and intermediaries in urban planning, as they are the protagonists in urban agriculture on the island.

In São Luís, agriculture is carried out in peri-urban space, while commercialization takes place in intraurban areas. Such finding opens room for exciting propositions for the urban planning of the island. For example, it is necessary to review the master plans of Paço do Lumiar, São José de Ribamar, and Raposa, to adapt them to the City Statute (BRASIL, 2008). It also points to the need for policies to articulate and integrate the metropolitan region as a means to encourage the discussion of the relationship among municipalities and, at the end of the day, improve the sociospatial indicators throughout the island.

Producers claimed that transportation and the poor conditions of the roads are the main obstacles to bring products to the markets, while most of the intermediaries did not answer. When asked about the vehicle used to transport the vegetables to the market, $44 \%$ of producers and $48 \%$ of intermediaries said they use chartered vehicles, while $35 \%$ and $32 \%$ have their vehicles, respectively. Only $17 \%$ of producers and $3 \%$ of intermediaries make use of vehicles provided by the government. Several problems appear daily in the production-market flow, including the lack of own and third-party vehicles 
(freight) to transport the products, poor conditions of vicinal roads, especially in the rainy season, slow traffic, and the lack of governmental support, among others.

Most producers own their farms $(92 \%)$, which stresses their vocation and stability towards agriculture and creates a strong background for the planning and adoption of public policies, including urban planning. The main vegetable crops are roselle (Hibiscus sabdariffa), green onions (Allium cepa) $\&$ coriander (Coriandrum sativum), and West Indian Gherkin (Cucumis anguria)
(Figure 3). These regional vegetables, well adapted to the climate and soil of the region, are easy to grow and, thus, have low production costs. Moreover, they are traditional in Maranhão cuisine, pleasant to the taste, are grown routinely, and have their culinary use culturally transmitted from one generation to the next. Tomato and onion are the vegetables most commercialized by intermediaries, although not originating from the local production. São Luís climatic conditions favor the high pressure of pests and diseases over tomato and onions, and the local market offers few adapted cultivars. Thus, tomato and onions are imported from neighboring producing states and purchased by the intermediaries at the São Luís wholesale market.

Half of the producers interviewed do not receive technical assistance, which potentially reduces yield and, consequently, sales and income. The lack of technical assistance also affects the use of pesticides once producers have no instructions on what to use, how to spray, and how to dispose of the empty packages. Indeed, two-thirds (69\%) of producers do not use chemicals.

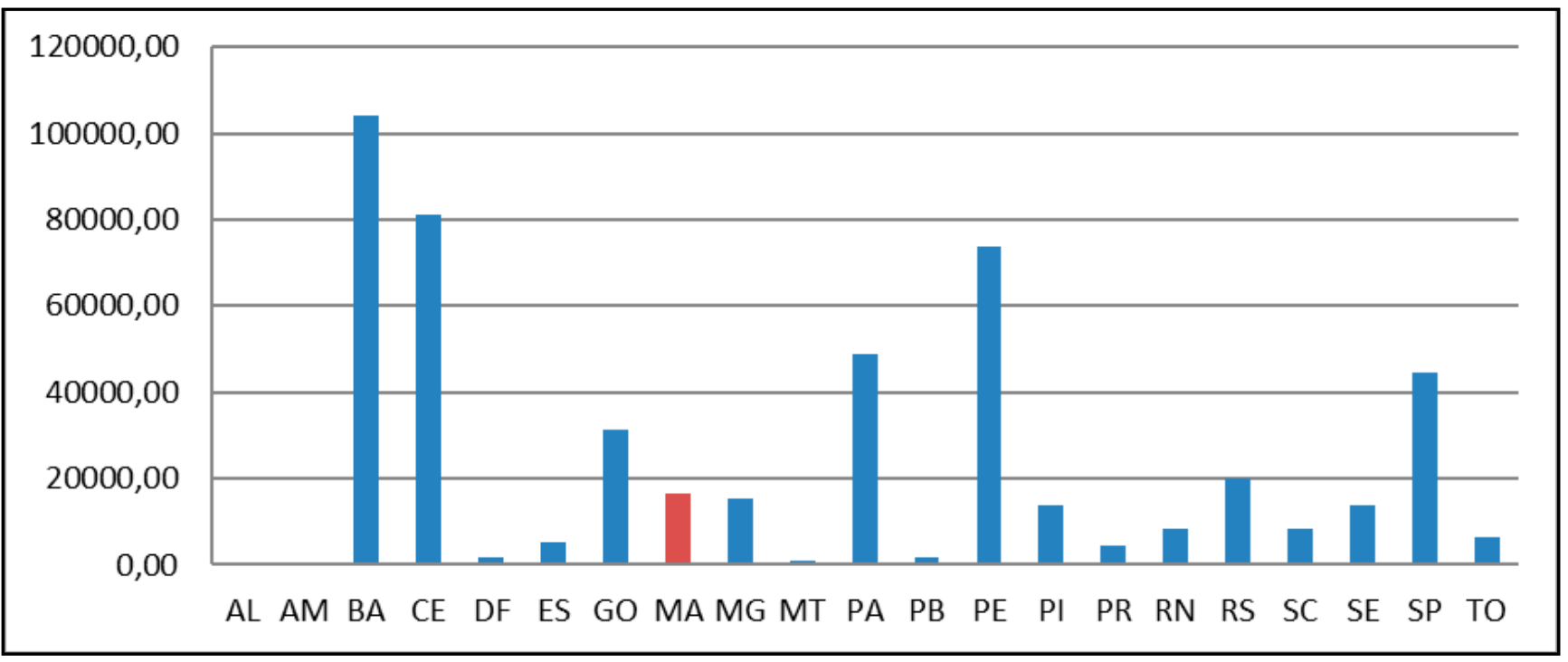

Figure 2.Value of the food products used to supply São Luís, in BRL\$, per state of origin (2013-jun/2016). Source: Cooperativa dos Hortifrutigranjeiros do Maranhão (2014, 2015, 2016). US\$ 1,00= BRL\$ 3,26 (in December 31, 2016. Central Bank of Brazil, https://www. bcb.gov.br/conversao). São Luís, Embrapa Cocais, 2016.

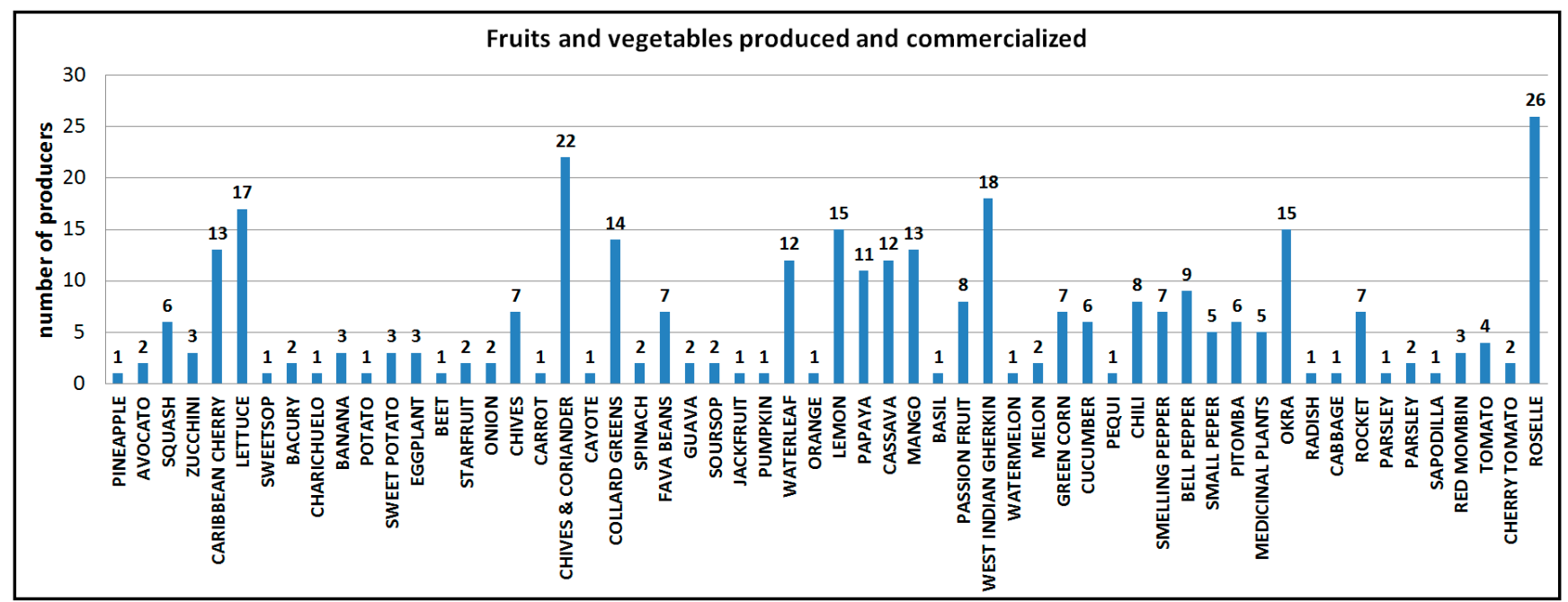

Figure 3. Leading fruits and vegetables produced and commercialized by the interviewed producers in São Luís Island. São Luís, Embrapa Cocais, 2016. 
Although the figure is significant, it is still disturbing that $31 \%$ of producers do use pesticides, the vast majority without any technical assistance. Aspects regarding the technical efficiency and appropriateness of the products to specific pests and crops, dosage, and grace periods need to be considered. Grace periods are compulsory written on the package leaflet. Observing the deadline is important to ensure food safety. Finally, it is necessary to check whether producers use Personal Protective Equipment (PPE) as a means of protecting them and the applicators from contamination. Interestingly, $79 \%$ of producers use some sustainable production techniques, such as green or organic fertilizer.

When asked about recycling the leftovers from the market, while $97 \%$ of producers responded, only $30 \%$ of intermediaries agreed to answer: $65 \%$ of producers and $76 \%$ of intermediaries use of leftovers. While producers mostly donate it (59\%), intermediaries resale the leftovers elsewhere (44\%), such as from door to door.

\section{FINAL CONSIDERATIONS}

We believe the successful experiences in urban agriculture worldwide confirm its multifunctionality, and the convergence of public policies on urban planning, agriculture and supply, education and health should strengthen it. In addition, it is necessary to understand the dynamics of urban agriculture, integrating it into the urban ecosystem to make it possible to develop new perspectives on the field-city relationship.

The main challenge of the urban agriculture value chain in São Luís is the fragmentation of production areas and the inherent spatial distances between production and commercialization. Knowing the causes of this phenomenon should be an important action in the urban planning of the island. Public policies need to consider and propose mechanisms to reduce the distances among the urban spaces that house agricultural activities, making them more compact.
The large number of public and private idlegreen areas in intra-urban spaces in São Luís could be earmarked for agricultural activities, complementing rural productivity and increasing both food security and incomes of urbanand peri-urban farmers. The existing intra-urban conservation units have large areas and can be interesting for the development of urban agriculture as well. Furthermore, urban agriculture can turn out to be a vector for protecting the natural resources and for fostering environmental education, if these areas are cultivated using agroecological principles.

As far as public policy integration is concerned, the implementation of a program to integrate the surplus of food produced by urban agriculture and the supply of government-assisted institutions is undoubtedly a great opportunity. Another feasible example is the integration of urban agriculture with the municipal solid waste management policy, which can potentially promote the improvement of the urban landscape and the mitigation of the severe sanitation and health problems arising from the accumulation of waste. As urban agriculture happens by definition within the city, it is also worth noting that preventive measures to avoid soil and groundwater contamination by pesticide and chemical fertilizer residues should be very strict, especially when there is risk of contamination of the water sources used to supply the population, in addition to the general damages to the environment.

The use of public policies to foster organic farming is a viable alternative to increase the added value of the products, besides being ecologically correct. Organic farming also benefits farmers' physical integrity and the conservation of natural resources by eliminating the use of chemicals. Therefore, urban agriculture, when combined with agroecological practices and organic production, is an important instrument for the mitigation of adverse environmental impacts on unproductive and anthropized green areas, and favors the protection of the existing natural resources, allowing their coexistence with human settlements.
In few words, the comprehensive approach used in this work to describe the reality indicates a lack of government support to urban farmers in São Luís, especially technical assistance, infrastructure (transport, roads), and technological support. These three dimensions should be included in public policies and programs.

\section{REFERENCES}

ARRUDA, J. 2011. Agricultura urbana na região metropolitana do Rio de Janeiro: sustentabilidade e repercussões na reprodução das famílias. Rio de Janeiro: UFRRJ.197p. (Ph.D. thesis).

ASSESSORIA E SERVIÇOS A PROJETOS EM AGRICULTURA ALTERNATIVA. 2015. Subsidio para uma política nacional de agricultura urbana e periurbana (PNAUP). Available at $<$ http://aspta.org.br/wp-content/ uploads/2015/04/Subsidio-para-umaPoli\%CC\%81tica-Nacional-de-AgriculturaUrbana-Periurbana.pdf $>$.Accessed March, $10,2016$.

BELO HORIZONTE. 2011. Lei $n^{o}$ 10.255, de 13 de setembro de 2011. Institui a política municipal de apoio à agricultura urbana $e$ dá outras providências. 2011. Available at $<$ https://leismunicipais.com.br/a/mg/b/belohorizonte/lei-ordinaria/2011/1026/10255/ lei-ordinaria-n-10255-2011-institui-a-politicamunicipal-de-apoio-a-agricultura-urbana-eda-outras-providencias. Accessed November $15,2016$.

BENEVOLO, L. 2011. História da cidade. São Paulo: Perspectiva. 728p.

BOUKHARAEVA, L; CHIANCA, G; MARLOIE, M.2007. Agricultura urbana como fenômeno universal. Available at http://www.latio. org/images/news/files/Chapitre $\% 20$ Agricultura\%20urbana\%2012\%20juin\%20 2007.pdf. Accessed September 10, 2016.

BOURQUE, M; CAÑIZARES, K. 2000. Agricultura urbana em Havana. Revista de Agricultura Urbana. 1: 1-8. Available at <http://www.ruaf.org/sites/default/files/ AU1havana.pdf $>$ Accessed May, 9, 2016.

BRASIL. 2008. Estatuto da Cidade. Brasília: Senado Federal, Subsecretaria de Edições Técnicas. 102p.

CASTELO BRANCO, M; HANSON, JC. 2011. Panorama das hortas comunitárias no Estados Unidos. In: CASTELO BRANCO, M; ALCÂNTARA FAA (eds). 2012. Hortas comunitárias: experiências do Brasil e dos Estados Unidos. v. 3. Brasília: Embrapa. p. 85-107.

FAO.FOOD AND AGRICULTURE ORGANIZATION. 2015. The state of food insecurity in the world: meeting the 2015 international hunger targets: taking stock of uneven progress. Rome.

GOMES, JFB. 2016. A multifuncionalidade 
da agricultura urbana e a sua integração no ecossistema urbano da ilha de São Luís, São Luís, MA. São Luís: UEMA. 161p. (M.Sc. thesis).

IBGE. INSTITUTO BRASILEIRO DE GEOGRAFIA E ESTATÍSTICA. 2011. Censo demográfico 2010. Rio de Janeiro. Available at http://www.ibge.gov.br/home/estatistica/ populacao/censo2010/. Accessed September 9, 2014.

IBGE. 2014. Maranhão: Infográficos: despesas e receitas orçamentárias e PIB. 2014a. Available at: http://cod.ibge.gov.br/1L1N $>$. Accessed July 11, 2016.

INSTITUTO MARANHENSE DE ESTUDOS SOCIOECONÔMICOS E CARTOGRÁFICOS. Maranhão em mapas: mapas temáticos do Estado do Maranhão. 2014. Available at $<$ http://imesc.ma.gov.br/ maranhaoemmapas/Home/mapas $>$. Accessed December 18, 2016.

MACHADO, AT; MACHADO, CTT. 2002. Agricultura urbana. Planaltina: Embrapa Cerrados. 25p. (Documents, 48.)

MAZOYER, M.; ROUDART, L. 2010. História das agriculturas no mundo: do neolítico à crise contemporânea

MOLDAKOV, O. 2000. Os agricultores urbanos de São Petersburgo. Revista de Agricultura Urbana 1:. 1-8. Available at http://www.ruaf.
org/sites/default/files/AU1 petersburg.pdf. Accessed May 9, 2016.

MOUGEOT, LJA. 2000a. Urban agriculture: definition, presence, potentials and risks, and policy challenges. Ottawa: International Development Research Centre. $58 \mathrm{p}$.

MOUGEOT, LJA.2000b. Agricultura urbana: conceito e definição. Revista de Agricultura Urbana 1: 1-8. Available at http://www. ruaf.org/sites/default/files/AU1 conceito.pdf. Accessed May 9, 2016.

PORTAL DA AGRICULTURA URBANA E PERIURBANA. 2016. Iniciativas produtivas. Available at http://agriculturaurbana.org.br/ iniciativas/menu01_inciativas_produtivas. html. Accessed March 10, 2016.

SANTANDREU, A; LOVO, IC. 2007. Panorama da agricultura urbana e periurbana no Brasil e diretrizes políticas para sua promoção: identificação e caracterização de iniciativas de AUP em regiões metropolitanas brasileiras. Belo Horizonte: REDE-IPES/RUAF, Available at: http://www.agriculturaurbana.org.br/textos/ panorama_AUP.pdf. Accessed July 15, 2016.

SÃO PAULO (Município). 2004. Lei ${ }^{\circ} 13.717$, de 8 de janeiro de 2004. Dispõe sobre a implantação das Terapias Naturais na Secretaria Municipal de Saúde, e dá outras providências. Available at http://www3.prefeitura.sp.gov.br/cadlem/ secretarias/negocios_juridicos/cadlem/integra. asp?alt $=09012004 \mathrm{~L} \% 20137170000$. Accessed
November 11, 2016.

SÃO PAULO (Município). 2016. Secretaria Municipal do Verde e do Meio Ambiente. Programa de agricultura urbana e periurbana. Availableat http://www.prefeitura.sp.gov.br/ cidade/secretarias/meio_ambiente/servicos/ proaurp/index.php? $\mathrm{p}=30091$. Accessed November 11, 2016.

SINIMBU, F. 2015. Uma horta agroecológica modelo. Available at https://www.embrapa. br/busca-de-noticias/-/noticia/3529851/ uma-horta-agroecologica-modelo. Accessed August 15, 2015.

SMIT, J; NASR J; RATTA, A. 2001. Urban agriculture: food, jobs and sustainable cities. Nova York: Programa das Nações Unidas para o Desenvolvimento. , 302p.

TERESINA. 2000. Secretaria Municipal de Agricultura e Abastecimento. Departamento de Produção. Estudo de caso: hortas comunitárias. In: SEMINÁRIO AGRICULTURA URBANA NAS CIDADES NO SÉCULO 21, Anais...Teresina. Available at: http://www. agriculturaurbana.org.br/sitio/textos/teresina. htm. Accessed March 15, 2016.

UNITED NATIONS. 2015. Department of Economic and Social Affairs. Population Division. World Urbanization Prospects: the 2014 revision. New York. CD-ROM. 